\title{
Performance of porous European mix (PEM) pavements added with crumb rubbers in dry process
}

Article in International Journal of Pavement Engineering · February 2015

DOI: $10.1080 / 10298436.2015 .1011783$

CITATIONS

2

2 authors:

\section{Zhaoxing Xie}

Auburn University

27 PUBLICATIONS 27 CITATIONS

SEE PROFILE
READS

55

Junan Shen

Georgia Southern University

49 PUBLICATIONS 644 CITATIONS

SEE PROFILE 
This article was downloaded by: [Georgia Southern University], [J. Shen]

On: 27 August 2015, At: 13: 18

Publisher: Taylor \& Francis

Informa Ltd Registered in England and Wales Registered Number: 1072954 Registered office: 5 Howick Place, London, SW1P IWG

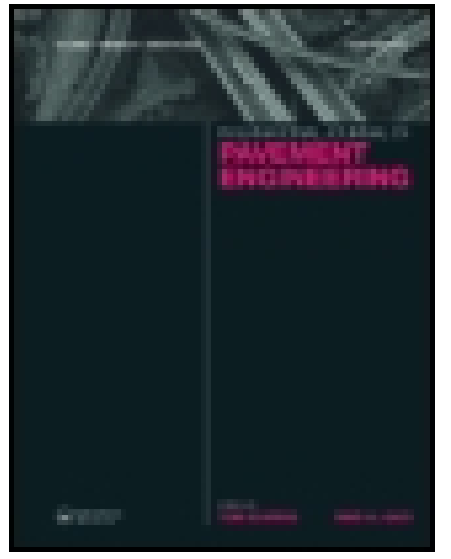

CrossMark

\section{International J ournal of Pavement Engineering}

Publication details, including instructions for authors and subscription information: http:// www. tandfonline.com/loi/gpav20

\section{Performance of porous European mix (PEM) pavements added with crumb rubbers in dry process}

\author{
${\text { Zhaoxing } \mathrm{Xie}^{\mathrm{a}} \text { \& J unan Shen }}^{\mathrm{b}}$ \\ a Department of Civil Engineering, Suzhou University of Science and Technology, Suzhou, \\ P. R. China \\ ${ }^{\mathrm{b}}$ Department of Construction Management and Civil Engineering Technology, Georgia \\ Southern University, Statesboro, GA, USA \\ Published online: 23 Feb 2015.
}

Click for updates

To cite this article: Zhaoxing Xie \& J unan Shen (2015): Performance of porous European mix (PEM) pavements added with crumb rubbers in dry process, International J ournal of Pavement Engineering, DOI: 10.1080/ 10298436. 2015.1011783

To link to this article: http:// dx. doi.org/ 10.1080/ 10298436.2015.1011783

\section{PLEASE SCROLL DOWN FOR ARTICLE}

Taylor \& Francis makes every effort to ensure the accuracy of all the information (the "Content") contained in the publications on our platform. However, Taylor \& Francis, our agents, and our licensors make no representations or warranties whatsoever as to the accuracy, completeness, or suitability for any purpose of the Content. Any opinions and views expressed in this publication are the opinions and views of the authors, and are not the views of or endorsed by Taylor \& Francis. The accuracy of the Content should not be relied upon and should be independently verified with primary sources of information. Taylor and Francis shall not be liable for any losses, actions, claims, proceedings, demands, costs, expenses, damages, and other liabilities whatsoever or howsoever caused arising directly or indirectly in connection with, in relation to or arising out of the use of the Content.

This article may be used for research, teaching, and private study purposes. Any substantial or systematic reproduction, redistribution, reselling, loan, sub-licensing, systematic supply, or distribution in any form to anyone is expressly forbidden. Terms $\&$ Conditions of access and use can be found at http:// www.tandfonline.com/page/terms-and-conditions 


\title{
Performance of porous European mix (PEM) pavements added with crumb rubbers in dry process
}

\author{
Zhaoxing Xie ${ }^{\mathrm{a}}$ and Junan Shen ${ }^{\mathrm{b}} *$ \\ ${ }^{a}$ Department of Civil Engineering, Suzhou University of Science and Technology, Suzhou, P.R. China; ${ }^{b}$ Department of Construction \\ Management and Civil Engineering Technology, Georgia Southern University, Statesboro, GA, USA
}

(Received 25 April 2014; accepted 10 January 2015)

\begin{abstract}
Crumb rubber modifier, made from scrap tires, has been introduced into the production of different types of hot mix asphalt in either wet or dry process. To determine if the rubberised asphalt mix performs as well as polymer-modified asphalt cement (PMAC), test sections of rubberised and control PMAC porous European mix (PEM) in Georgia were examined through a visual inspection and laboratory testing. The results indicated that the performance of rubberised PEM pavements from visual inspection was almost equal to that of PMAC PEM (as the controls) with no rutting or cracking being found, except that the Cantabro test showed a higher mass loss after 3 years' service. After 5 years' service in I-75 Perry, the rubberised PEM still performed a little better rutting resistance, although the rubberised section experienced about twice cumulative traffic as compared to the control; the other visual inspections remained the same.
\end{abstract}

Keywords: crumb rubber modifier (CRM); porous European mix (PEM); dry process; field performance

\section{Introduction}

Crumb rubber modifier (CRM), made from scrap tires, has been introduced into the production of hot mix asphalt (HMA) because it improves the mechanical properties of HMA and is an effective way of dealing with the waste tires (Rahman 2004, Cooper et al. 2007, Lee et al. 2007, Xiao et al. 2007, Shen et al. 2009). CRM was introduced to the asphalt mixtures by two different techniques: wet process and dry process. In the wet process, $10-25 \%$ by mass of asphalt binder, the finer crumb rubber (less than $1 \mathrm{~mm})$ was mixed with asphalt at high temperature (170$205^{\circ} \mathrm{C}$ ) to form asphalt rubber, which is then mixed with aggregate in a drum to produce HMA. In the dry process, $1-3 \%$ by mass of the total aggregate, a larger crumb rubber $(1-8 \mathrm{~mm})$ is mixed directly with aggregate in the drum to produce an HMA called rubberised asphalt mix (Rahman 2004).

Considerable research indicated that the wet process exhibited better resistance to permanent deformation and fatigue compared to conventional mixtures (Hicks et al. 1995, Oliver 2000, Huang et al. 2002, Hunt 2002, Kaloush et al. 2003). Many researchers investigated the influence of CRM on the performance properties of porous asphalt mixtures and reported that HMA made with truck tire rubber generally performed better in porosity, initial permeability and provided stable long-term drain down results when compared to passenger car tire rubber, and the addition of CRM reduced the moisture susceptibility of porous asphalt mixtures (Lyons 2012, Love 2014).
In the dry process, most of the previous works have considered that the wet process had sufficient interaction between asphalt and CRM due to long time blending at high temperature, while asphalt-CRM reaction in the dry process is negligible due to the shorter reaction period and larger particle sizes used (Rahman 2004). However, recent research found that during the mixing period as well as transportation and laying, the asphalt-CRM reaction in the dry process is significantly higher than previously thought and improves the performance of HMA (Singleton 2000, Rahman et al. 2010, Hernández-Olivares et al. 2009, López-Moro et al. 2013). In addition, field performance of the dry process CRM mixture is inconsistent and the service life varies from 2 to 20 years (Rahman 2004). The dry process in Oregon performed worse compared to the wet process and conventional method (Hunt 2002). On the other hand, the dry process test sections in Louisiana experienced similar or better fatigue and rutting resistance after 5-7 years" service (Huang et al. 2002). The dry process test sections of open graded mixture in Kansas showed acceptable rutting but cracking had formed in all areas after 5 years' service (Fager 2001). There are possible reasons for poor field performance in the dry process, such as the lack of aggregate-to-aggregate contact and interlock because of larger CRM particle size, higher CRM content used and non-uniform distribution of CRM in HMA.

Recently, smaller size CRM (less than $1 \mathrm{~mm}$ ), lower CRM content (about 10\% mass of asphalt binder) and a cross-link agent (transpolyoctenamer [TOR] polymer)

*Corresponding author. Email: jshen@ georgiasouthern.edu 
were used in the dry process to improve the performance of HMA in Georgia (Sheila 2007, Shen and Xie 2012, Xie and Shen 2013). Crumb rubber is added as a substitute for the PMAC normally required to produce a PG 76-22 in three types of HMA: porous European mix (PEM), stone matrix asphalt (SMA) and polymer-modified $12.5 \mathrm{~mm}$ Superpave mixtures in Georgia (Shen and Xie 2012). To compare the field performance of rubberised asphalt mix and control PMAC, test sections of rubberised and control PMAC PEM were paved on I-75 Valdosta (2009), I-20 Augusta (2009) and I-75 Perry (2007) in Georgia. So far, neither a formal evaluation has been performed nor has research on these rubberised pavements generally been documented. Collecting data to evaluate their field performance after 3 and 5 years' service is urgently needed to determine if the rubberised asphalt mix performs as well as control PMAC.

\section{Objective}

The objective of this study was to evaluate the field performance of rubberised PEM pavements with different service times of 3 and 5 years and to determine if rubberised PEM performs as well as PMAC PEM pavements. This evaluation is to be conducted through a visual inspection on the testing pavements including pavement distresses such as rutting, cracking, ravelling and potholes. In addition, laboratory tests for the physical and durability properties of cored samples also were performed.

\section{Information of test sections}

Rubberised and control PEM test sections as wearing course were paved on I-75, Valdosta, in 2009 and I-75, Perry, in 2007, respectively. In addition, only rubberised PEM was paved as surface layer on both eastbound and westbound of I-20, Augusta, in 2009. It is noted that the rubberised (eastbound) and control PMAC (westbound)
SMA mixtures were constructed under the rubberised PEM surface layer on I-20 Augusta. The test sections in I75 Valdosta and I-20 Augusta were the full-depth pavement, and the test sections in I-75 Perry were the cement-stabilised base pavement. Tables 1 and 2 present the construction and traffic volume on the three test sections, respectively. Only cumulative traffic volume was calculated because of no traffic composition was available for calculating the equivalent single axle load. Table 2 indicates that the rubberised test section in I-75 Valdosta experienced slightly higher cumulative traffic, and the rubberised PEM in I-75 Perry had about twice cumulative traffic, compared to the control.

\section{Mix design and materials}

For the rubberised PEM test section, - 30 mesh was used at $10 \%$ of the weight of the base binder of PG 67-22. CRM is introduced and mixed directly with aggregates and PG 67-22 asphalt in the drum to produce the PEM. The crosslink agent (TOR) was used at $4.5 \%$ of the weight of the CRM (TOR were the white particles in the container on the left of Figure 1). A volumetric feed system was set up at the asphalt plant to incorporate the blended crumb rubber/ TOR material (see container on the left side of Figure 1) into the reclaimed asphalt pavement collar through the pipe (see the right side of Figure 1) at the drum.

For control PMAC PEM test section, SBS-modified asphalt binder (PG76-22) was used. For both rubberised and control PEM test sections, the same asphalt binder content (6.0\%), and aggregate type (granite aggregate) and aggregate gradation (Table 3) were used (Sheila 2007). Granite aggregate was used for both PEM mixtures. Both rubberised and control PEM mixtures had the similar mixing temperature $\left(160^{\circ} \mathrm{C}\right)$ and compaction temperature $\left(157^{\circ} \mathrm{C}\right)$.

Cantabro test has been used to evaluate the PEM resistance to ravelling (Lu and Harvey 2011). The test was conducted on the samples of both control PEM and the rubberised one. Average-\%-loss results obtained from a

Table 1. Information of test sections.

\begin{tabular}{|c|c|c|c|c|c|c|}
\hline \multicolumn{2}{|c|}{ PEM test section } & \multirow{2}{*}{$\begin{array}{c}\text { Design } \\
\text { thickness } \\
\text { (inch) }\end{array}$} & \multirow{2}{*}{$\begin{array}{c}\begin{array}{c}\text { Construction } \\
\text { date } \\
\text { (year) }\end{array} \\
2009\end{array}$} & \multirow{2}{*}{$\begin{array}{c}\begin{array}{c}\text { Investigation } \\
\text { date (year) }\end{array} \\
2012\end{array}$} & \multirow{2}{*}{$\begin{array}{c}\begin{array}{c}\text { Length } \\
\text { (mile) }\end{array} \\
17\end{array}$} & \multirow{2}{*}{$\begin{array}{l}\text { Orientation } \\
\text { Southbound }\end{array}$} \\
\hline I-75 Valdosta & Rubberised & & & & & \\
\hline & Control & 1.25 & 2009 & 2012 & 17 & Northbound \\
\hline \multirow[t]{2}{*}{ I-20 Augusta } & $\begin{array}{l}\text { Rubberised } \\
\text { (with rubberised } \\
\text { SMA underlayer) }\end{array}$ & 1.25 & 2009 & 2012 & 2.15 & Eastbound \\
\hline & $\begin{array}{l}\text { Rubberised } \\
\text { (with PMAC } \\
\text { SMA underlayer) }\end{array}$ & 1.25 & 2009 & 2012 & 2.15 & Westbound \\
\hline \multirow[t]{2}{*}{ I-75 Perry } & Rubberised & 1.25 & 2007 & 2012 & 1 & Northbound: outer lane \\
\hline & Control & 1.25 & 2007 & 2012 & 1 & $\begin{array}{l}\text { Northbound: inner and } \\
\text { centre lanes }\end{array}$ \\
\hline
\end{tabular}


Table 2. Traffic volume of test sections.

\begin{tabular}{|c|c|c|c|c|c|c|c|c|}
\hline & \multirow{2}{*}{$\begin{array}{l}\text { Test section } \\
\text { PEM }\end{array}$} & \multicolumn{6}{|c|}{ Annual average daily traffic (AADT) } & \multirow[b]{2}{*}{ Cumulative traffic volume } \\
\hline & & 2012 & 2011 & 2010 & 2009 & 2008 & 2007 & \\
\hline \multirow[t]{2}{*}{ I-75 Valdosta } & Rubberised & 20,190 & 20,330 & 21,930 & 21,730 & N/A & N/A & $18,940,200$ (3 lanes) \\
\hline & Control & 20,360 & 19,790 & 21,260 & 21,200 & N/A & N/A & 18,493,200 (3 lanes) \\
\hline \multirow[t]{2}{*}{ I-20 Augusta } & $\begin{array}{l}\text { Rubberised, Eastbound (with } \\
\text { rubberised SMA } \\
\text { underlayer }^{\text {a }} \text { ) }\end{array}$ & 25,800 & 25,640 & 25,510 & 24,650 & N/A & N/A & 22,989,000 (3 lanes) \\
\hline & $\begin{array}{l}\text { Rubberised,Westbound } \\
\text { (with PMAC } \\
\text { SMA underlayer }{ }^{\mathrm{a}} \text { ) }\end{array}$ & 26,060 & 25,440 & 25,060 & 24,130 & N/A & N/A & $22,755,000$ (3 lanes) \\
\hline \multirow[t]{2}{*}{ I-75 Perry } & Rubberised & 13,337 & 13,286 & 14,805 & 14,149 & 13,475 & 15,882 & $23,087,247$ (outer lane $^{\mathrm{b}}$ ) \\
\hline & Control & 7832 & 7803 & 8695 & 8310 & 7914 & 9327 & $\begin{array}{c}\text { 13,559,253 (inner and } \\
\text { centre lanes }^{b} \text { ) }\end{array}$ \\
\hline
\end{tabular}

${ }^{a}$ The rubberised and control SMA pavements were constructed under the PEM surface layer on I-20 Augusta in 2009. All eastbound lanes are rubberised SMA, while all westbound lanes are control SMA pavements.

${ }^{\mathrm{b}}$ Lane distribution factor, 0.63 for outer lane, 0.30 for centre lane, 0.07 for inner lane (Pavement Design Manual, Georgia).

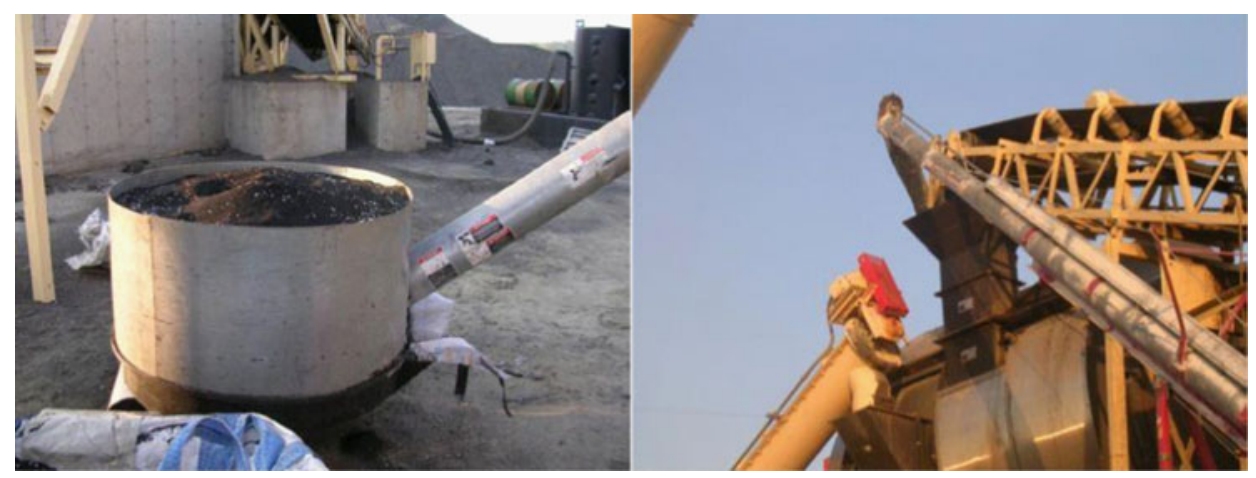

Figure 1. Blended crumb rubber/TOR feeder container and pipe (Sheila 2007).

Table 3. Aggregate gradation of PEM.

\begin{tabular}{lrlllll}
\hline Sieve $(\mathrm{mm})$ & 19 & 12.5 & 9.5 & 4.75 & 2.36 & 0.075 \\
Percentage passing (\%) & 100 & 90 & 50 & 14 & 8.0 & 3.0 \\
\hline
\end{tabular}

plant-produced mix for control PEM and rubberised PEM were on average $18.6 \%(17.0 \%, 17.9 \%$ and $20.8 \%)$ and $19.1(22.7 \%, 17.0 \%$ and $17.5 \%)$, respectively (Sheila 2007), and met the Georgia Department of Transportation's expected performance rate of less than $20 \%$.

\section{Sampling plan}

The core samples in wheel paths and the lane centres in each test section were drilled after 3 years' of service for I-75 Valdosta and I-20 Augusta, and 5 years' of service for I-75 Perry. Since wheel paths are subject to repeated traffic loading, core samples taken from wheel paths should differ from those taken between them. To determine the influence of traffic loading on pavement physical properties and durability, the same number of cores in wheel paths and the lane centres in each test section was drilled. Because sampling on a busy interstate highway requires traffic control such as closing lanes, the number of samples was practically restricted. A total of 48 specimens were taken from the testing sections and used in this study. The number of the samples was not based on the requirement to make a statistic analysis, i.e. statistics point of view. Table 4 shows the sampling plan of all core samples. In order to make full use of the core samples, the non-destructive test (specific gravity and permeability) was performed first and then destructive test (Cantabro test) was conducted.

\section{Evaluation methods}

The long-term performance of rubberised and control PEM test sections were evaluated by the visual inspection in the field and testing of core samples in laboratory. The visual field inspection included a series of distress measurements in accordance with Georgia Department of Transportation Pavement Condition Evaluation System 
Table 4. PEM cores.

\begin{tabular}{|c|c|c|c|c|}
\hline \multicolumn{2}{|c|}{ Test Section } & \multirow{2}{*}{$\begin{array}{c}\text { Location } \\
\text { Lane centre }\end{array}$} & \multirow{2}{*}{$\begin{array}{c}\begin{array}{c}\text { Number of } \\
\text { samples cored }\end{array} \\
6\end{array}$} & \multirow{2}{*}{$\begin{array}{c}\begin{array}{c}\text { Number of core } \\
\text { samples tested }\end{array} \\
6\end{array}$} \\
\hline I-75 Valdosta & Rubberised PEM & & & \\
\hline & & Wheel path & 6 & 6 \\
\hline & Control PEM & Lane centre & 6 & 6 \\
\hline & & Wheel path & 6 & 6 \\
\hline & Total & & 24 & 24 \\
\hline \multirow[t]{3}{*}{ I-20 Augusta } & Rubberised PEM & Lane centre & 6 & 4 (two samples broken) \\
\hline & & Wheel path & 6 & 6 \\
\hline & Total & & 12 & 10 \\
\hline \multirow[t]{5}{*}{ I-75 Perry } & Rubberised PEM & Lane centre & 3 & 3 \\
\hline & & Wheel path & 3 & 3 \\
\hline & Control PEM & Lane centre & 3 & 3 \\
\hline & & Wheel path & 3 & 3 \\
\hline & Total & & 12 & 12 \\
\hline
\end{tabular}

(PACES) manual, such as cracking, rut depth, ravelling, bleeding, pushing and potholes. Laboratory investigations on the samples included the physical and durability properties such as density, permeability and Cantabro test.

\subsection{In situ tests}

\subsubsection{Rut depth}

Rut depth was measured in both wheel paths in the sample area and recorded in millimetres $(\mathrm{mm})$. Rutting measurements was taken by 'blocking' up the stringline using a block of hollow steel pipe (Figure 2).

\subsubsection{Cracking}

The length of the cracking was measured and the level of the severity was recorded.

\subsubsection{Ravelling, bleeding and pushing}

The length of the distresses was measured and the level of the severity was recorded.

\subsubsection{Pothole}

The total number of potholes was counted for the entire rated segment (normally a mile).

\subsection{Laboratory tests}

\subsubsection{Bulk specific gravity}

The bulk specific gravity of the PEM samples was measured using the Corelok method following AASHTO T 331and AASHTO T 166, respectively.

\subsubsection{Maximum specific gravity}

Maximum specific gravity of the core samples was conducted according to ASTM D6857-03 Standard Test Method.

\subsubsection{Permeability}

Permeability was measured using the Karol-Warner Flexible Wall Permeameter. The apparatus and testing procedures are detailed in ASTM PS 129-01.

\subsubsection{Skid resistance test}

Skid resistance in the wheel paths of PEM pavements was measured by a portable skid resistance tester according to AASHTO T 278-90 (2012).

\subsubsection{Cantabro test}

Core sample durability, i.e., potential of resistance to ravelling, is normally evaluated using the Cantabro test. For example, the core samples are weighed and placed in a Los Angeles Abrasion Tester without the use of the steel ball, and the drum was turned for special revolutions. The percentage of mass loss during this process is used to evaluate the resistance of the core sample to ravelling.

The percentage of mass lost is used to evaluate the core sample's resistance to ravelling. Cantabro loss was calculated using the following formula:

$$
\mathrm{CL}=\frac{(A-B)}{A \times 100}
$$

where $\mathrm{CL}$ is the Cantabro loss, \%; $A$ is the initial weight of test specimen and $B$ is the final weight of the test specimen.

A standard number of revolutions, 300, are normally used for the Marshall sample with a standard thickness of 
(a)

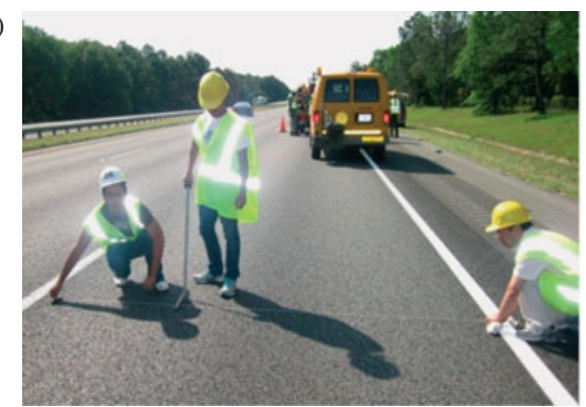

Rut Measurement

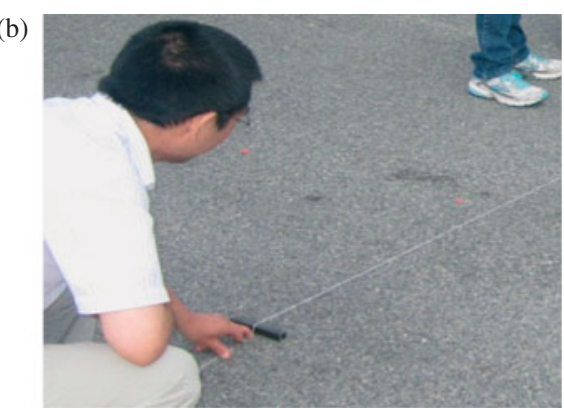

“Blocking” Up Stringline Using Steel Pipe

Figure 2. (a) Rut measurement and (b) 'blocking' up stringline.

$63.5 \mathrm{~mm}$. The core samples taken from the test sections, like 'hockey puck', were much thinner than the standard Marshall sample. The results of Cantabro test showed that core sample thickness influenced significantly the Cantabro loss. Figure 3 showed a typical relationship between the mass loss and the thickness for samples from I-75, Valdosta. A trend was obvious: the thicker the sample, the less the Cantabro loss. Tests on the samples from other two sections had similar trend as those from I-75 Valdosta.

In addition, the aged severity of asphalt mix had significant effect on the Cantabro results. Figures 4 and 5 show the samples of 3- and 5-year periods after 40 revolutions, respectively. The rubberised sample of the 3year period (Figure 4(a)) had much more whole aggregates falling from the sample while the control example (Figure 4(b)) had much more fine particles abraded from the sample. The rubberised sample (Figure 5(a)) of the 5year period obviously was broken more seriously than the control sample (Figure 5(b)).

It is not possible to use the standard revolution of 300 for the aged 'hockey puck' samples since they will break at much less revolution. In this research, trials of Cantabro test were made on the different cores to determine the suitable number that is defined at which the sample starts to break. Finally, 40, 10 and 40 were used for the core samples taken from I-75 Valdosta, I-75 Perry and I-20 Augusta, respectively.

\section{Results and discussions}

\subsection{Field performance}

\subsubsection{I-75 Valdosta}

Table 5 summarised I-75 Valdosta pavement performance as measured by rut depth, cracking, ravelling, bleeding, pushing and potholes. After 3 years of' service, the field performance of the rubberised PEM pavement is obviously similar to that of the control PEM pavement. Cracking, ravelling, bleeding, pushing and potholes were not found in either, and only two profiles of the control PEM pavement near milepost 10 showed a minor problem: a rutting depth of $2 \mathrm{~mm}$.

Table 5. Results of field inspection.

\begin{tabular}{|c|c|c|c|c|c|c|c|c|c|c|c|c|c|}
\hline \multirow[b]{3}{*}{ Test section } & \multirow[b]{3}{*}{ Pavement type } & \multirow[b]{3}{*}{ Cracking } & \multirow[b]{3}{*}{ Ravelling } & \multirow{3}{*}{$\begin{array}{l}\text { Bleeding, } \\
\text { pushing } \\
\text { and pothole }\end{array}$} & \multirow{3}{*}{$\begin{array}{c}\text { Skid } \\
\text { resistance } \\
(\mathrm{BPN}) \\
\text { Average }\end{array}$} & \multicolumn{8}{|c|}{ Rut depth (mm) } \\
\hline & & & & & & \multicolumn{8}{|c|}{ Section } \\
\hline & & & & & & 1 & 2 & 3 & 4 & 5 & 6 & 7 & 8 \\
\hline \multirow{2}{*}{$\begin{array}{l}\text { I-75 Valdosta } \\
\text { (3 year service) }\end{array}$} & Rubberised PEM & None & None & None & 61 & 0 & 0 & 0 & 0 & 0 & 0 & 0 & 0 \\
\hline & Control PEM & None & None & None & 57 & 0 & 0 & 0 & 0 & 0 & 0 & 2 & 2 \\
\hline \multirow{2}{*}{$\begin{array}{l}\text { I-20 Augusta } \\
\text { (3 year service) }\end{array}$} & Westbound & None & None & None & 54 & 0 & 0 & 0 & 0 & 0 & 0 & 0 & 0 \\
\hline & $\begin{array}{l}\text { Eastbound } \\
\text { rubberised PEM }\end{array}$ & None & None & None & 58 & 0 & 0 & 0 & 0 & 0 & 0 & 0 & 0 \\
\hline \multirow[t]{2}{*}{$\begin{array}{l}\text { I-75 Perry } \\
(5 \text { year service) }\end{array}$} & Rubberised PEM & $\begin{array}{l}\text { Interval }=9 \mathrm{~m} \\
\text { length }=3.7 \mathrm{~m} \\
\text { width }=1.2-2.5 \mathrm{~cm}\end{array}$ & $\begin{array}{l}7 \mathrm{~m} \text { at the } \\
\text { beginning } \\
\text { of whole lane }\end{array}$ & None & 49.8 & 2 & 2 & 1 & 3 & 2 & 3 & 1 & 2 \\
\hline & Control PEM & $\begin{array}{l}\text { Similar to } \\
\text { rubberised PEM }\end{array}$ & None & None & 49.1 & 4 & 3 & 5 & 3 & 6 & 4 & 4 & 4 \\
\hline
\end{tabular}




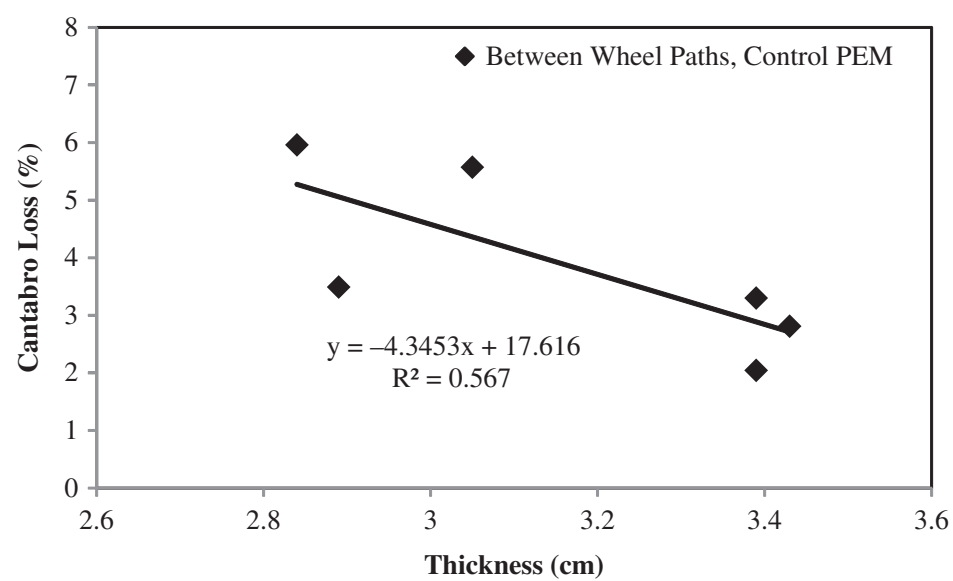

Figure 3. Relationship between thickness and Cantabro loss after 40 revolutions in core samples, I-75 Valdosta.

(a)

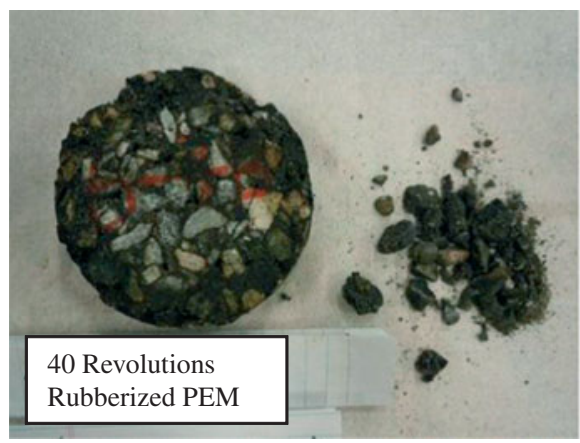

Rubberized PEM (b)

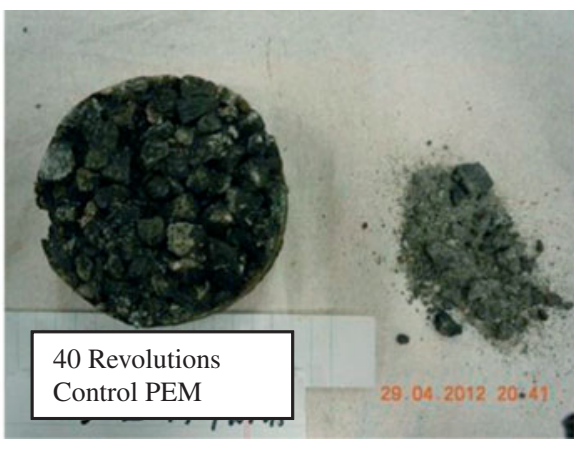

Control PEM

Figure 4. Condition of 3-year service cores after 40 revolutions. (a) Rubberised PEM and (b) control PEM.

(a)

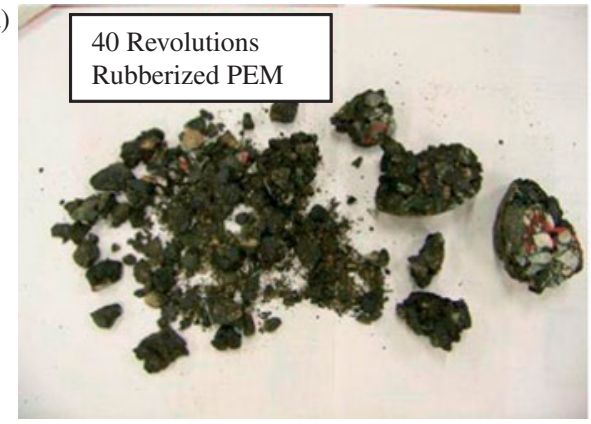

Rubberized PEM

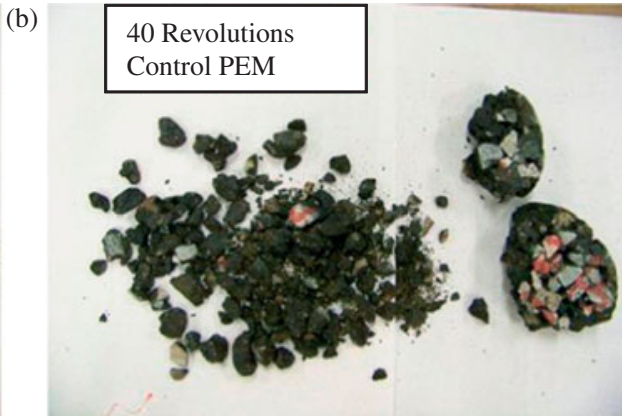

Control PEM

Figure 5. Condition of 5-year service cores after 40 revolutions. (a) Rubberised PEM and (b) control PEM.

\subsubsection{I-20 Augusta}

Table 5 presented I-20 Augusta pavement performance as measured by cracking, rut depth, ravelling, bleeding, pushing, and potholes. As mentioned, rubberised PEM pavement was placed in both the eastbound and westbound lanes, while a rubberised SMA was used under the eastbound lane and SMA modified with SBS was used under the westbound lane. Neither test section showed distress.

\subsubsection{I-75 Perry}

Table 5 presented I-75 Perry pavement performance as measured by cracking, rut depth, ravelling, bleeding, pushing and potholes. Again, the rubberised and control PEM pavements perform similarly after 5 years of service, except for 24 feet at the beginning of the rubberised PEM test section. Neither bleeding nor pushing was found in either. Average rut depths for the rubberised and control PEM test sections were 2 and $4 \mathrm{~mm}$, respectively, 
which are still very low. In addition, although the rubberised section had almost twice cumulative traffic compared to the control, the rubberised PEM still performed a little better rutting resistance, indicating the performance of rubberised PEM in I-75 Perry is superior to the control.

In addition, cracking was observed in both rubberised and control PEM test sections, and their length and severity were similar. Most cracking crossed over the lane at $9 \mathrm{~m}$ intervals. Widths varied from 1.2 to $2.5 \mathrm{~cm}$. The beginning of the rubberised PEM test section showed about $7 \mathrm{~m}$ of ravelling to the adjacent to PMAC-modified pavement, which may be attributed to incorrect construction. Another possible reason may be that the rubber particles did not have enough time to react with asphalt, and as a result, the rubberised mixtures did not perform as well as those paved in the later section.

For the I-75 Valdosta wheel path, the rubberised PEM pavement test section was slightly more skid resistant than the control PEM pavement, and performance was similar in both I-20 Augusta east- and westbound lanes and the I75 Perry wheel path.

\subsection{Laboratory performance of PEM core samples}

Results of the specific gravity, air voids, permeability and Cantabro loss values were statistically analysed with a 5\% level of significance. An analysis of variance was performed to statistically analyse the data.

\subsubsection{I-75 Valdosta}

It is noted that the rubberised PEM samples had slightly lower values of bulk specific gravity than the control PEM samples for the wheel path and those between the wheel paths, respectively (Figure 6). The air voids of the rubberised PEM samples for the wheel path and between the wheel paths are 9.8, which is $6.9 \%$ higher than that of the control PEM pavement, respectively (Figure 7). The rubberised PEM samples had higher values of permeability than the controls. This contributed to higher air voids of the rubberised PEM mix. The rates of difference of permeability for the wheel path and between the wheel paths are $34.4 \%$ and $38.5 \%$, respectively (Figure 8). Statistical analysis in Table 6 indicates that there were significantly different specific gravity, air voids and permeability values between the rubberised and control PEM.

Figure 9 shows that the rubberised PEM samples had higher values of Cantabro Loss than the controls. Table 6 indicates that Cantabro Loss of rubberised PEM samples was significantly different from that of control PEM. It was observed that the rubberised samples were easier to have abrasion than the controls. However, it was also

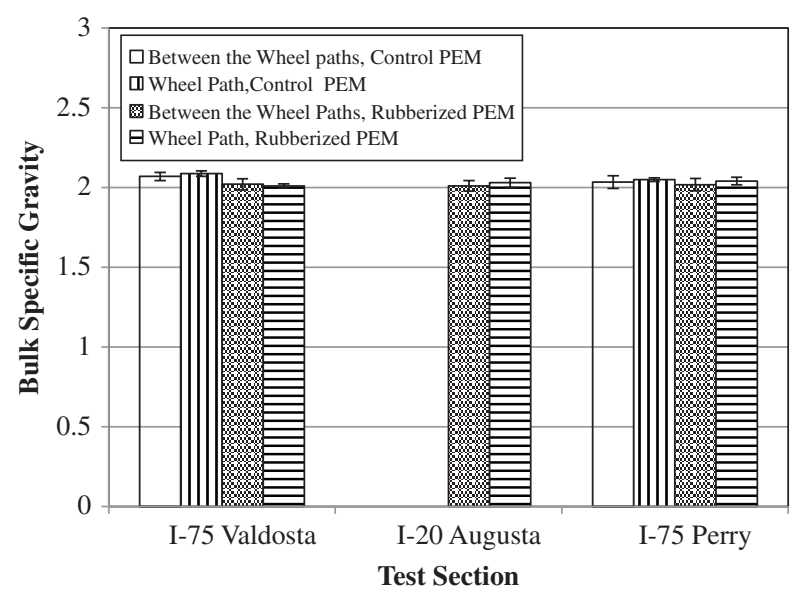

Figure 6. Average bulk specific gravity of PEM core samples.

found that the deviation of the results of Cantabro loss, especially for the rubberised PEM, is very high. It may be caused by difficulty to evaluate accurately the mass loss of the rubberised mixture samples that are aged and thin. Due to limited sample, it is difficult to improve the deviation in this study.

\subsubsection{I-20 Augusta}

The surface of the I-20 Augusta testing section is rubberised PEM in both directions, and rubberised and control SMA sections were paved under the PEM layer in the eastbound and westbound lanes, respectively, so we could observe how it performs with two different underlayers of rubberised and control PEM. Figures 6-8 show that the rubberised PEM with a rubberised SMA underlayer was slightly less dense, with more air voids and permeability, than the section with a control SMA underlayer. Figure 9 shows that the two conditions have similar Cantabro loss values. Table 6 indicates that

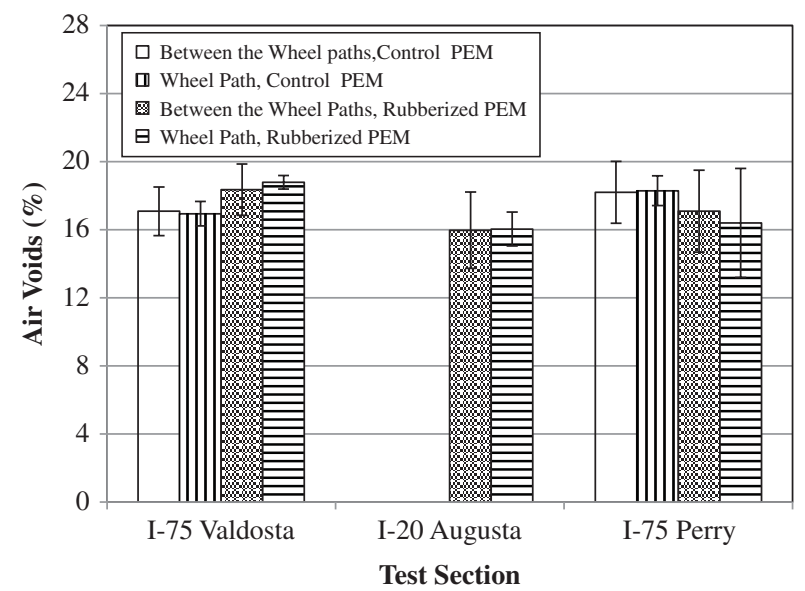

Figure 7. Average air voids of PEM core samples. 


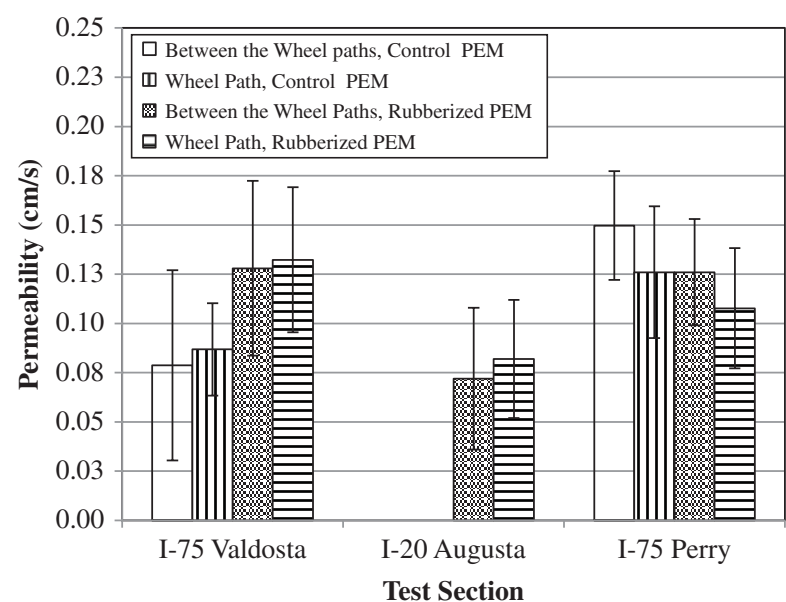

Figure 8. Average permeability of PEM core samples.

Table 6. Statistical analysis of properties of PEM core samples.

\begin{tabular}{lccc}
\hline Properties & I-75 Valdosta & I-75 Perry & I-20 Augusta \\
\hline $\begin{array}{c}\text { Rubberised- } \\
\text { control } \\
\text { Bulk Specific }\end{array}$ & $\begin{array}{c}\text { Rubberised- } \\
\text { control } \\
\mathrm{N}^{\mathrm{b}}\end{array}$ & $\begin{array}{c}\text { Eastbound- } \\
\text { westbound }\end{array}$ \\
$\begin{array}{l}\text { Gravity } \\
\text { Air Voids }\end{array}$ & $\mathrm{Y}$ & $\mathrm{Y}$ & $\mathrm{N}$ \\
Permeability & $\mathrm{Y}$ & $\mathrm{N}$ & $\mathrm{N}$ \\
Cantabro Loss & $\mathrm{Y}$ & $\mathrm{N}$ & $\mathrm{N}$ \\
\hline
\end{tabular}

${ }^{\mathrm{a}} \mathrm{Y}$ : $p$-value $<\alpha=0.05$ (significant difference).

${ }^{\mathrm{b}} \mathrm{N}$ : $p$-value $>\alpha=0.05$ (no significant difference).

${ }^{\mathrm{c}}$ Only rubberised PEM was paved on both eastbound and westbound of I20, Augusta, while the rubberised (eastbound) and control PMAC (westbound) SMA mixtures were constructed under the rubberised PEM.

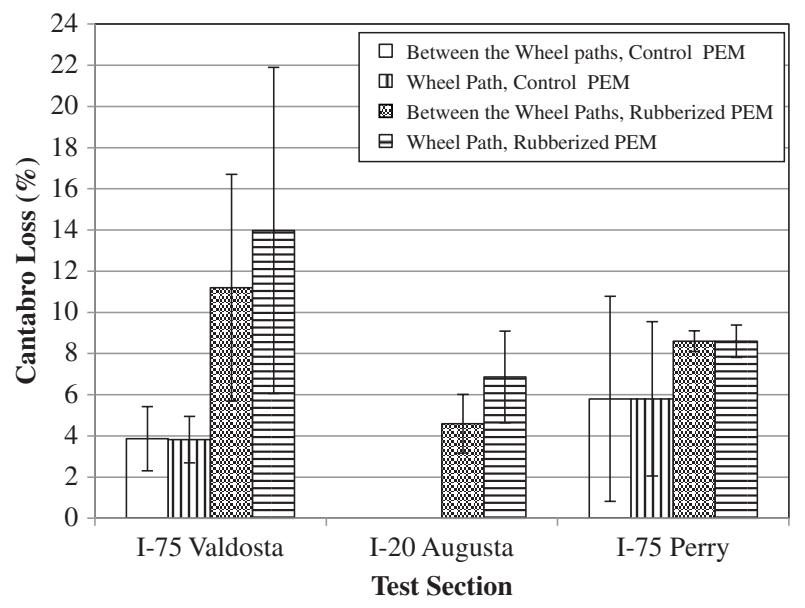

Figure 9. Average Cantabro loss of PEM core samples.

gravity, air voids, permeability and Cantabro loss values of rubberised PEM samples with rubberised SMA underlayer were not significantly different with that of rubberised PEM with control SMA underlayer. Hence, rubberised and control SMA underlayers have no significant effect on surface PEM.

Figures 6 and 7 show that the wheel path of the rubberised PEM pavement has similar values of bulk specific gravity and air voids to the pavement between thee wheel paths. Figure 8 showed that the wheel path has slightly higher values of permeability than that of the centre of the lane. Figure 9 illustrates Cantabro loss of the wheel path to be higher than that of the centre of lane. It may be contributed to more traffic loading on the wheel path than the centre of lane. In the Cantabro test, loss was calibrated to a thickness of $3.3 \mathrm{~cm}$ for cored sample according to the regression equation.

\subsubsection{I-75 Perry}

Bulk specific gravity values for both the wheel path and the area between were slightly lower for the rubberised PEM pavement than the control (Figure 6). The air voids of the rubberised PEM wheel path and centre lane were $11.6 \%$ and $6.4 \%$ lower, respectively, than those of the control PEM (Figure 7). Permeability values for the rubberised PEM were lower than the control's due to fewer air voids. Difference rates for the wheel path and between were $17.0 \%$ and $18.8 \%$, respectively (Figure 8 ). Statistical analysis in Table 6 indicates that there were no significant different specific gravity and permeability values between the rubberised and control PEM, except air voids.

Figure 9 shows that the rubberised PEM had higher Cantabro loss values than the control even though the void ratio was lower than that of the control samples. Table 6 indicates that Cantabro Loss of rubberised PEM samples was not significantly different with that of control PEM. The test comprised 10 revolutions, and loss was calibrated to the value of a $2.8 \mathrm{~mm}$ core samples using the regression equation. These results did not distinguish wheel path from the centre lane because of too few core samples.

\subsection{Effects of time on rubberised PEM properties}

Table 7 showed changes in the measured properties of core samples as service life increases. Note that the 5-year rubberised PEM had similar bulk specific gravity, slightly fewer air voids and better permeability than the 3-year samples, while the 5-year control PEM had slightly lower bulk specific gravity, slightly more air voids and better permeability than the 3-year sample, possibly due to differences in the properties of the original mixtures.

In order to evaluate the effects of time on Cantabro loss of rubberised PEM, the situation of core samples from I-75 Perry after 40 revolutions was used to compare with those from I-75 Valdosta and I-20 Augusta. Cantabro loss after 5 years was much worse than after 3 years for both rubberised and control samples. After 40 revolutions, the 
Table 7. Core sample property changes over time.

\begin{tabular}{|c|c|c|c|c|c|}
\hline \multirow[b]{2}{*}{ Properties } & & \multicolumn{3}{|c|}{ Three years } & \multirow{2}{*}{$\begin{array}{l}\text { Five years } \\
\text { I-75 Perry }\end{array}$} \\
\hline & & I-75 Valdosta & I-20 Augusta & Average & \\
\hline \multirow[t]{4}{*}{ Rubberised PEM } & Bulk specific gravity & 2.02 & 2.02 & 2.02 & 2.03 \\
\hline & Air voids $(\%)$ & 18.6 & 16.1 & 17.4 & 16.8 \\
\hline & Permeability $(\mathrm{cm} / \mathrm{s})$ & 0.13 & 0.077 & 0.103 & 0.117 \\
\hline & Cantabro loss ${ }^{\mathrm{a}}(\%)$ & 13 & 5.7 & 9.4 & Broken \\
\hline \multirow[t]{4}{*}{ Control PEM } & Bulk specific gravity & 2.08 & None & 2.08 & 2.04 \\
\hline & Air voids $(\%)$ & 17.1 & None & 17.1 & 18.2 \\
\hline & Permeability $(\mathrm{cm} / \mathrm{s})$ & 0.083 & None & 0.083 & 0.138 \\
\hline & Cantabro loss ${ }^{\mathrm{a}}(\%)$ & 4.2 & None & 4.2 & Broken \\
\hline
\end{tabular}

${ }^{\text {a }}$ Core samples from I-75 Valdosta, I-75 Perry, and I-20 Augusta were subjected to 40 revolutions.

3-year core samples from I-75 Valdosta showed some abraded particles (Figure 4), while the 5-year core samples from I-75 Perry broke into pieces (Figure 5). In both rubberised and control PEM, the Cantabro loss became larger with increased service life.

\section{Summary and conclusions}

This paper presented a preliminary evaluation of the longterm performance of rubberised PEM pavements, compared to the PMAC PEM pavement as a control, using the visual field inspection and laboratory investigation on cored samples. The results indicated the rubberised PEM, i.e., crumb rubber added in dry process, performed well in the field after a service life of 3 and 5 years, and the rubberised PEM works equally as PMAC PEM for the service years evaluated.

The following conclusions can be obtained from the present research:

- After a 3-year' service, the field performance of the rubberised PEM pavement was similar to that of the control. The distresses of cracking, rutting, ravelling, bleeding, pushing and potholes were not found in the rubberised PEM pavement from both I-75 Valdosta and I-20 Augusta. Only two profiles of the PMAC PEM pavement near milepost 10 of I-75 Valdosta showed minor rutting of $2 \mathrm{~mm}$.

- After a 5-years' service, the field performance of the rubberised PEM pavement was similar to that of the control PEM pavement. Neither showed any bleeding or pushing, while all profiles of both showed rutting. The I-75 Perry rubberised PEM pavement had shallower ruts than the control PEM pavement. Although the rubberised section had almost twice cumulative traffic compared to the control, the rubberised PEM still performed a little better rutting resistance than the control, indicating that the performance of rubberised PEM in I-75 Perry is superior to the control.
- Both I-75 Perry PEM test sections had reflection cracking. The length and severity for the rubberised pavement were similar to that of the control and had nothing to do with the mixtures. The 24-foot ravelling found only at the very beginning of the rubberised PEM test section may be attributed to improper construction procedures and lack of enough time for the rubber to reach binder to form quality mixtures.

- The 3-year rubberised PEM samples had lower bulk specific gravity, better permeability and much more Cantabro loss than the controls. The 5-year rubberised PEM mixture had lower bulk specific gravity, lower permeability and much more Cantabro loss than the controls.

- Cantabro loss tests, measured using modified number of rotation, showed that the values of the Cantabro loss increased with increased service life for both rubberised and control PEM. The Cantabro loss had a big deviation due to the difficulty of measuring the aged and thin 'hockey puck' samples. Mass loss from modified Catanbro test did not reflect well the performance from visual inspection of the pavements.

\section{Funding}

This study was sponsored by Georgia Department of Transportation (Project No. 11-19), to which the writers are very grateful.

\section{References}

Cooper, S.B., et al., 2007. Evaluation of field projects using crumb rubber modified asphaltic concrete. Publication FHWA/LA.04/393. Baton Rouge, LA: FHWA, U.S. Department of Transportation.

Fager, G.A., 2001. Asphalt rubber: a summary of the use of crumb rubber in the hot mixes: Kansas experience 19902000. Topeka, KS: Kansas Department of Transportation.

Hernández-Olivares, F., et al., 2009. Rubber-modified hot-mix asphalt pavement by dry process. International Journal of Pavement Engineering, 10 (4), 277-288. 
Hicks, R.G., et al., 1995. Crumb rubber modifier in asphalt pavement - summary of practice in Arizona, California and Florida. Publication FHWA-SA-95-056. Corvallis, OR: FHWA, U.S. Department of Transportation.

Huang, B., et al., 2002. Louisiana experience with crumb rubber-modified hot-mix asphalt pavement. In: Transportation Research Record: Journal of the Transportation Research Board. Washington, DC: Transportation Research Board of the National Academies, $1-13$.

Hunt, E.A., 2002. Crumb rubber modified asphalt concrete in Oregon. Final Report SPR 355. Salem, OR: Oregon Department of Transportation.

Kaloush, K., Sotil, A., and Way, G., 2003. Dynamic modulus properties of asphalt rubber mixtures. 3rd international symposium on maintenance and rehabilitation of pavements and technological control Guimaraes: University of Minho.

Lee, S.J., et al., 2007. Laboratory study of the effects of compaction on the volumetric and rutting properties of CRM asphalt mixtures. Journal of Materials in Civil Engineering, 19 (12), 1079-1089. doi:10.1061/(ASCE)0899-1561(2007) 19:12(1079).

López-moro, F.J., Moro, M.C., et al., 2013. Microscopic analysis of the interaction between crumb rubber and bitumen in asphalt mixtures using the dry process. Construction and Building Materials, 48, 691-699. doi:10.1016/j.conbuildmat.2013.07.041.

Love, K.N., 2014. Influence of different rubber modified binder variables on performance properties of porous asphalt mixtures. Clemson, SC: Clemson University.

Lu, Q. and Harvey, J.T., 2011. Laboratory evaluation of opengraded asphalt mixes with small aggregates and various binders and additives. In: Transportation Research Record: Journal of the Transportation Research Board. Washington, DC: Transportation Research Board of the National Academies, 61-69.
Lyons, K.R., 2012. Evaluation of rubber modified porous asphalt mixtures. Clemson, SC: Clemson University.

Oliver, J.W.H., 2000. Rutting and fatigue properties of crumbed rubber hot mix asphalts. In: Jorge B. Sousa, ed. Conference on asphalt rubber, Vilamoura, 221-240.

Pavement Design Manual, Georgia Department of Transportation 2005.

Rahman, M., 2004. Characterization of dry process crumb rubber modified asphalt mixtures. Nottingham: University of Nottingham.

Rahman, M., Airey, G.D., and Collop, A.C., 2010. Moisture susceptibility of high and low compaction dry process crumb rubber-modified asphalt mixtures. In: Transportation Research Record: Journal of the Transportation Research Board. Washington, DC: Transportation Research Board of the National Academies, 121-129.

Sheila, H., 2007. Crumb rubber test section on CSNHS-M003-00 (560) 01 Houston Peach, Special Research Report 2007-1. Atlanta, GA: Georgia Department of Transportation.

Shen, J., et al., 2009. Influence of surface area and size of crumb rubber on high temperature properties of crumb rubber modified binders. Construction and Building Materials, 23 (1), 304-310. doi:10.1016/j.conbuildmat.2007.12.005.

Shen, J. and Xie, Z., 2012. Comprehensive evaluation of the longterm performance of rubberized pavement: phase I: laboratory study of rubberized asphalt mix performance, FHWA-GA-121119. Statesboro, GA: Georgia Department of Transportation.

Singleton, T.M., 2000. Characterization of impact absorbing asphalt. Nottingham: University of Nottingham.

Xiao, F., Amirkhanian, S.N., and Juang, C.H., 2007. Rutting resistance of rubberized asphalt concrete pavements containing reclaimed asphalt pavement mixtures. Journal of Materials in Civil Engineering, 19 (6), 475-483. doi:10. 1061/(ASCE)0899-1561(2007)19:6(475).

Xie, Z. and Shen, J., 2013. Long-term performance of SMA mixtures added with crumb rubbers in dry process. Airfield and Highway Pavement, Los Angeles, CA, 1145-1155. 